of Vyg, when it was ruled by both Denisovs and then by Ivan Filipov. It is a detailed investigation of this self-governing monastic settlement whose structure very much resembles those of the monasteries and autonomous northern parishes of Northern Russia. It is truly amazing that, despite the development of autocracy and endless persecutions, Vyg was able to preserve its own independent spirit and organization.

The book is attractive, has many useful plans, maps, and pictures which help the reader to understand the life of this semimonastic settlement, and is supplied with an almost exhaustive bibliography. It is certainly a praiseworthy contribution to the history of eighteenth-century Russia.

SERGE A. ZENKOVSKY

Vanderbilt University

\title{
DIE SPANISCH-RUSSISCHEN BEZIEHUNGEN IM 18. JAHRHUNDERT.
}

By Ana Maria Schop Soler. Veröffentlichungen des Osteuropa-Instituts München, vol. 35. Wiesbaden: Otto Harrassowitz, 1970. 264 pp. DM 48, paper.

With balance and care the author has told the story of diplomatic relations between Spain and Russia from the time of Peter the Great to the end of the reign of Paul I. Spanish statesmen were well aware of the significance of Russia in the balance of power and also in the European economy; this account of their activity is a useful addition to the historiography of European diplomacy.

Of particular value is Soler's exploitation of archival material in Italy and Spain. A number of original Spanish documents appear in the appendix, along with some tables showing the development of trade. Unfortunately, through no fault of her own, the author was unable to use Russian archival sources, but she has used Russian printed documents. For British policy she has relied on the standard secondary sources. She provides a full account of the general line of Spanish foreign policy and the various pressures that influenced Russian attitudes; however, she ends the book abruptly, with no conclusion. The reader gets the impression that Spain was one of the minor concerns of the Russian rulers and that Spain's conduct was sometimes visionary-for example, in her use of diplomats who represented the exiled Stuarts and even in her hope at one time for Russian armed intervention against England on behalf of that ill-fated house. The author provides additional documentation for the already known interest of Spain in cultivating Russia as a foil to England, and shows the growing attention of Spain to Russian involvement in the Mediterranean.

The book contains an extensive description of Spanish-Russian trade relations at the beginning and toward the end of the eighteenth century. The greater part of the book deals with the reign of Catherine II. The author has little to say about cultural relations between the two countries and does not discuss the impact of the "anti-Spanish tradition" on Russian literature, which has been treated ably in Dieter Boden's Das Amerikabild im russischen Schriftum bis zum Ende des 19. Jahrhunderts (Hamburg, 1968). Citations from Russian and Swedish sources have been translated into German, while Spanish, French, and English quotations have been left in the original. The lack of a conclusion testifies to the complex nature of eighteenth-century diplomacy, with its changing alliances and frequent wars. Though the author provides no new interpretations or material that alters 
commonly accepted views of this period, she has brought to light a number of letters that will be of use to the European historian.

\author{
FrankLIN A. WALKer \\ Loyola University, Chicago
}

THE RUSSIAN ANNEXATION OF THE CRIMEA, 1772-1783. By Alan $W$. Fisher. Cambridge: Cambridge University Press, 1970 . xvi, 180 pp. $\$ 9.50$.

This is a good narrative of the struggle of two powers to dominate the Crimea. Fisher has uncovered a wealth of information from Turkish archives and from published Turkish and Russian sources. He describes the problems of the Crimean peoples, who wished merely to follow their own interests, the Ottoman Empire which endeavored to maintain its hegemony, and the Russian Empire which sought to supplant it. With the ascendancy of Russia's power, the loyalty of the Crimean peoples to Turkish sovereignty was strained, and this threatened the northern defense perimeter of the ever-weakening Ottoman Empire. With her victory in the Russo-Turkish War of 1768-74, Catherine achieved a settlement which permitted the Crimea a semblance of independence but allowed Russia a greater influence there than ever before. Independence did not produce any greater unity among the Crimean peoples, and any attempt by a khan to assert autocratic authority met with forceful opposition. Khan S. Sahin Giray, hand-picked by Catherine, did not always follow her every wish. During his reign from 1777 to $1782-83$, because he was an ineffectual leader and administrator, his attempted reforms to Westernize or Russianize the Crimea failed miserably. The Crimea suffered greatly from indigenous revolts, Ottoman military thrusts, and full-scale Russian invasions. Annexation remained the only alternative for Catherine to secure firmly this volatile territory and people.

Fisher is at his best when dealing with Ottoman and Crimean subjects. As for Russia, he makes only cursory mention of divisions of opinion on policy without exploring fully the decision-making process at the Russian court. Nor is there more than incidental recognition of the commercial worth of both the Crimea and the Black Sea to Russia, especially at a time when Catherine was initiating a broad policy of commercial expansion. A further elaboration of Catherine's policy toward the Crimea in the context of Russian foreign policy at that time would have been desirable.

HERBERT H. KaPLAN

Indiana University

\title{
TSAR ALEXANDER I: PATERNALISTIC REFORMER. By Allen
} McConnell. New York: Thomas Y. Crowell, 1970. viii, 232 pp. \$2.25, paper.

In this brief biography, designed primarily for use in undergraduate history courses, McConnell has synthesized the vast bibliography of older works on Alexander I's reign as well as a number of recent works on some of the less well known aspects of the Alexandrine age. Although the book contains little that will startle scholars working on this period, it will certainly help destroy various stereotypes long cherished by nonspecialists (the hackneyed division of Alexander's reign into clear-cut "liberal" and "reactionary" phases, the exaggerated emphasis upon Arakcheev, the idea that Alexander's inconsistencies resulted from weakness and an inability to control his advisers, etc.). McConnell has convincingly pointed up 